Jurnal Akuntansi dan Investasi, Vol. 18 No. 1, Hlm: 48-65, Januari 2017

Artikel ini tersedia di website: http://journal.umy.ac.id/index.php/ai

DOI: $10.18196 /$ jai.18160

\title{
Determinan Sinkronisasi Dokumen Anggaran Pendapatan dan Belanja Daerah (APBD) dengan Dokumen Kebijakan Umum Anggaran dan Prioritas Plafon Anggaran Sementara (KUA-PPAS) Kota Mataram Tahun 2015
}

\author{
Dwi Anugrah Putra*; Prayitno Basuki; Sri Pancawati Martiningsih \\ Program Magister Akuntansi Universitas Mataram, Jl. Pemuda No. 35 Mataram, NTB, Indonesia
}

\begin{tabular}{l}
\hline A R T I C L E I N F O \\
\hline Article history: \\
received 13 Mar 2015 \\
revised 30 Mei 2016 \\
accepted 18 Jul 2016
\end{tabular}

Keywords:

Human Resource

Capacity;

Budget Planning;

Budgeting Politics;

Public Policy;

Public Transparency

\begin{abstract}
AB S TRACT
The purpose of this study is to analyze the effect of human resources capacity, budget planning, budgeting politics and public policy to the synchronization of APBD document and KUA-PPAS document, with the public transparency as moderating variable. The population of this study was board member and officer/staff that involved in the preparation of RKA-SKPD document. This study using purposive sampling technique, which is then analyzed by the multiple regression analysis and moderated regression analysis. Partial results of hypothesis testing showed that human resources capacity, budget planning and budgeting politic has significant positive effect, while the public policy does not affect to the synchronization of APBD document and KUA-PPAS document. The results of moderated regression analysis showed that the public transparency as moderating variable failed to moderate the relationship between human resources capacity, budget planning, budgeting politics and the public policy with the synchronization of APBD document and KUA-PPAS document. The implications of this study may provide an explanation for the basic concept of synchronization in the process of preparing documents for planning and budgeting, provide benefits in the practice of planning and budgeting, as well as provide input and consideration for Local Government, in determining policies relating to the synchronization of planning and budgeting documents.
\end{abstract}

(C) 2017 JAI. All rights reserved

\section{PENDAHULUAN}

Bergulirnya era reformasi menyebabkan terjadinya peralihan sistem sentralisasi menjadi desentralisasi, sehingga sejumlah kewenangan pusat beralih ke daerah. Sistem desentralisasi tersebut mencakup desentralisasi keuangan negara yang ditujukan untuk menjalankan prinsip anggaran yang disertai dengan fungsi dan tanggung jawab yang telah didelegasikan kepada daerah.

Kebijakan otonomi daerah di Indonesia telah membawa perubahan yang sangat mendasar terhadap hubungan eksekutif dengan legislatif. Hal ini menunjukkan bahwa di antara legislatif dan eksekutif terjadi hubungan keagenan (Halim dan Abdullah, 2006). Perubahan ini juga berimplikasi pada semakin besarnya peran legislatif dalam pembuatan kebijakan publik, termasuk penganggaran di pemerintah daerah. Perencanaan dan pe- nganggaran sendiri merupakan dua hal yang erat kaitannya. Agar perencanaan dan penganggaran bersifat realistik dan tepat sasaran, maka perlu didukung oleh peraturan pemerintah yang menjabarkan konsep dan ketentuan lebih rinci mengenai kerangka rencana dan anggaran. Permendagri No. 21 tahun 2011 merupakan pedoman dalam pelaksanaan, penatausahaan Anggaran Pendapatan dan Belanja Daerah (APBD), pelaporan keuangan dan juga kebijakan akuntansi.

Mekanisme penyusunan anggaran di daerah telah diatur dalam sejumlah peraturan perundangundangan. Mekanisme penganggaran ini melibatkan berbagai pihak yang mempunyai latar belakang yang berbeda baik dari tingkat pemahaman terhadap anggaran maupun dari kepentingan terhadap anggaran. Perbedaan ini diyakini dapat menyebabkan terjadinya ketidaksinkronan dalam proses pembuatan anggaran, yaitu antara 
dokumen APBD dengan Kebijakan Umum Anggaran dan Prioritas Plafon Anggaran Sementara (KUA-PPAS) (Iskandar, 2013).

Ketidaksinkronan antara dokumen APBD dengan dokumen KUA-PPAS terjadi hampir di setiap pemerintah daerah. Faktor-faktor yang mempengaruhi sinkronisasi antara dua dokumen tersebut yaitu kapasitas sumber daya manusia, politik penganggaran, perencanaan, dan informasi pendukung (Amirudin, 2009). Yandra (2011) mengemukakan bahwa penyebab ketidakkonsistenan antara dokumen PPAS dan APBD antara lain: (1) terjadi bencana alam pada rentang waktu setelah penyusunan PPAS; (2) adanya dana dari pusat yang hadir pada rentang waktu setelah penyusunan PPAS; (3) ketidakmatangan SKPD dalam menyusun PPAS; (4) kebijakan pemerintah tentang pelaksanaan sebuah program; dan (5) adanya tekanan politis untuk mengadakan suatu kegiatan pada APBD.

Hasil Evaluasi Rancangan Peraturan Daerah Kota Mataram tentang APBD Tahun Anggaran 2015 dan Rancangan Peraturan Walikota Kota Mataram tentang Penjabaran APBD Tahun Anggaran 2015 diketahui bahwa masih terdapat ketidaksinkronan antara KUA-PPAS yang diajukan oleh eksekutif dengan APBD yang disetujui oleh legislatif. Ketidaksinkronan ini tidak sejalan dengan amanat UU 25/2004 tentang Sistem Perencanaan Pembangunan Nasional, dan Peraturan Pemerintah No 58. Tahun 2005 tentang Pengelolaan Keuangan Daerah.

Penelitian ini merupakan pengembangan dari penelitian Iskandar (2013) yang bertujuan untuk memberikan bukti empiris bahwa Kapasitas Sumber Daya Manusia, Perencanaan Anggaran, dan Politik Penganggaran akan mempengaruhi Sinkronisasi Dokumen APBD dengan Dokumen KUA-PPAS, dengan Tranparansi Publik sebagai pemoderasi. Perbedaan penelitian ini dengan penelitian Iskandar (2013) adalah ditambahkannya variabel Kebijakan Publik, yang di dalam penelitian Yandra (2011) dinyatakan menjadi salah satu penyebab ketidakkonsistenan antara dokumen PPAS dan APBD.

Perencanaan dan penganggaran merupakan dua hal yang erat kaitannya. Fenomena yang terjadi selama ini menunjukkan bahwa perencana cenderung mengabaikan keterkaitan antar dokumen perencanaan dan penganggaran (Yandra (2011). Hal ini mendorong peneliti ingin mengetahui faktor-faktor yang mempengaruhi Sinkronisasi Dokumen APBD dan Dokumen KUAPPAS, beserta variabel moderasinya. Hasil dari penelitian ini diharapkan dapat memberikan bukti secara empiris mengenai sinkronisasi dokumen APBD dengan dokumen KUA-PPAS yang proses pembahasannya melibatkan legislatif dan eksekutif. Hasil penelitian ini juga diharapkan dapat memberikan manfaat dalam praktik perencanaan dan penganggaran, terutama dalam hal keterkaitan antar dokumen perencanaan. Hasil penelitian ini juga diharapkan dapat memberikan masukan dan pertimbangan bagi Pemerintahan Daerah, dalam menentukan kebijakan yang berhubungan dengan sinkronisasi dokumen perencanaan dan penganggaran.

\section{TINJAUAN LITERATUR DAN PERUMUSAN HIPOTESIS}

\section{Teori Keagenan}

Jensen dan Meckling (1976) menjelaskan hubungan keagenan di dalam Teori Keagenan (Agency Theory), bahwa perusahaan merupakan kumpulan kontrak (nexus of contract) antara pemilik sumber daya ekonomis (principa) dan manajer (agent) yang mengurus penggunaan dan pengendalian sumber daya tersebut. Menurut Messier et al. (2006), hubungan keagenan ini mengakibatkan dua permasalahan, yaitu: (1) terjadinya informasi asimetris (information asymmetry), dimana manajemen secara umum memiliki lebih banyak informasi mengenai posisi keuangan yang sebenarnya dan posisi operasi entitas dari pemilik; dan (2) terjadinya konflik kepentingan (conflict of interest) akibat ketidaksamaan tujuan, di mana manajemen tidak selalu bertindak sesuai dengan kepentingan pemilik.

Halim dan Abdullah (2006) menemukan bahwa: (1) hubungan dan masalah keagenan dalam penganggaran antara eksekutif dan legislatif merupakan bagian tak terpisahkan dalam penelitian keuangan (termasuk akuntansi) publik, politik penganggaran, dan ekonomika public; (2) eksekutif merupakan agen bagi legislatif dan publik (dual accountability) dan legislatif agen bagi public; (3) konsep perwakilan (representativeness) dalam penganggaran tidak sepenuhnya berjalan ketika kepentingan publik tidak terbela seluruhnya oleh karena adanya perilaku oportunistik (moral hazard) legislative; dan (4) eksekutif sebagai agen cenderung menjadi budget maximizer karena berperilaku oportunistik (adverse selection dan moral hazard sekaligus). 


\section{Teori Implementasi Kebijakan}

Studi implementasi merupakan suatu kajian mengenai studi kebijakan yang mengarah pada proses pelaksanaan dari suatu kebijakan. Dalam praktiknya, implementasi kebijakan merupakan suatu proses yang begitu kompleks bahkan tidak jarang bermuatan politis dengan adanya intervensi berbagai kepentingan (Agustino, 2012).

Dalam sejarah perkembangan studi implementasi kebijakan dijelaskan mengenai adanya dua pendekatan guna memahami implementasi kebijakan, yaitu: pendekatan top down dan bottom up. Pendekatan top down memahami implementasi kebijakan sebagai sesuatu yang tersentralisir dan dimulai dari aktor tingkat pusat, dan keputusannya pun diambil di tingkat pusat. Pendekatan top down bertitik-tolak dari perspektif bahwa keputusan politik (kebijakan) yang telah ditetapkan oleh pembuat kebijakan harus dilaksanakan oleh administrator/birokrat yang ada pada level dibawahnya (Agustino, 2012).

Penelitian ini menggunakan teori implementasi kebijakan berperspektif top down yang dikembangkan oleh George C. Edward III (1980). Edward III (1980) menamakan model implementasi kebijakan publiknya dengan Direct and Indirect Impact on Implementation. Pendekatan teori ini mengemukakan empat variabel yang mempengaruhi keberhasilan impelementasi suatu kebijakan, yaitu: (1) Komunikasi; (2) Sumber daya; (3) Disposisi; dan (4) Struktur birokrasi (Agustino, 2012).

\section{Kapasitas Sumber Daya Manusia}

Sumber daya manusia merupakan pilar penyangga utama sekaligus penggerak roda organisasi dalam usaha mewujudkan visi dan misi serta tujuan dari organisasi tersebut (Wiley, 2007). Sumber daya manusia (human resources) merujuk kepada orang-orang di dalam organisasi untuk mencapai tujuan organisasi (Simamora, 2001). Sumber Daya adalah salah satu variabel yang menurut Edward III (1980) dapat mempengaruhi keberhasilan implementasi suatu kebijakan. Sumber daya yang di dalamnya termasuk sumber daya manusia, merupakan hal penting dalam mengimplementasikan suatu kebijakan(Agustino, 2012).

Amirudin (2009) mengemukakan bahwa kapasitas sumber daya manusia adalah kemampuan dari anggota eksekutif maupun legislatif dalam menjalankan fungsi dan perannya masing-masing dalam proses penyusunan kebijakan dalam pengelolaan keuangan daerah. Iskandar (2013) mengemukakan bahwa kapasitas sumber daya manusia berpengaruh siginifikan terhadap sinkronisasi dokumen APBD dengan dokumen KUAPPAS. Hipotesis yang dapat dirumuskan berdasarkan uraian tersebut adalah sebagai berikut:

H1: Terdapat pengaruh kapasitas sumber daya manusia terhadap sinkronisasi dokumen APBD dengan dokumen KUA-PPAS.

\section{Perencanaan Anggaran}

Halim dan Abdullah (2006) menemukan bahwa hubungan dan masalah keagenan dalam penganggaran antara eksekutif dan legislatif merupakan bagian tak terpisahkan dalam penelitian keuangan (termasuk akuntansi) publik, politik penganggaran, dan ekonomika publik. Stiglitz (1999) menyatakan bahwa masalah keagenan terjadi pada semua organisasi, baik publik maupun privat, khususnya dalam proses perencanaan dan penganggaran. Rasyid (2012) mengemukakan bahwa Dokumen Peraturan Daerah tentang APBD yang telah disahkan tidak sinkron dengan dokumen perencanaan yang telah disepakati. Ketidaksinkronan ini terjadi akibat dari kurangnya instrumen perencanaan terkait dengan proses penganggaran di pemerintah daerah. Garis besar proses penyusunan dalam penetapan anggaran didasarkan pada rangkaian tahapan (siklus). Apabila perencanaan pada tahapan awal buruk maka akan berdampak pada buruk perencanaan pada tahap berikutnya. Hipotesis yang dapat dirumuskan berdasarkan uraian tersebut adalah sebagai berikut:

H2: Terdapat pengaruh perencanaan anggaran terhadap sinkronisasi dokumen APBD dengan dokumen KUA-PPAS.

\section{Politik Penganggaran}

Hubungan principal dan agen terjadi setiap kali tindakan seseorang individu memiliki efek pada individu lain atau ketika satu individu tergantung pada tindakan lain (Gilardi, 2001). Menurut Moe (1984) dan Strom (2000), hubungan keagenan dalam penganggaran publik adalah antara (1) pemilih-legislator; (2) legislatorpemerintah; (3) menteri keuangan-pengguna anggaran; (4) perdana menteri-birokrat; dan (5) pejabat-pemberi pelayanan. Hal yang sama dikemukakan juga oleh Gilardi (2001), yang melihat hubungan keagenan sebagai hubungan pendelegasian (chains of delegation). 
Peran utama legislatif dalam proses politik penyusunan APBD, menurut Amirudin (2009), terlihat jelas saat pembahasan KUA-PPAS serta dalam penetapan Perda APBD. Dalam pembahasan anggaran, eksekutif dan legislatif membuat kesepakatan-kesepakatan (bargaining) yang dicapai melalui proses politik dengan acuan KUA dan PPAS sebelum anggaran ditetapkan sebagai suatu peraturan daerah. Hal itu terjadi karena legislatif mempunyai hak budgeting yang diwujudkan dalam menyusun dan menetapkan APBD bersamasama dengan pemerintah daerah.

Rasyid (2012) mengemukakan bahwa Dokumen Peraturan Daerah tentang APBD yang telah disahkan tidak sinkron dengan dokumen perencanaan yang telah disepakati. Ketidaksinkronan ini terjadi akibat dari faktor politik pada proses penganggaran di pemerintah daerah. Iskandar (2013) mengemukakan bahwa politik penganggaran berpengaruh positif signifikan terhadap sinkronisasi dokumen APBD dengan dokumen KUAPPAS. Hipotesis yang dapat dirumuskan berdasarkan uraian tersebut adalah sebagai berikut:

H3: Terdapat pengaruh politik penganggaran terhadap sinkronisasi dokumen APBD dengan dokumen KUA-PPAS.

\section{Kebijakan Publik}

Dye (1978) mendefinisikan kebijakan publik merupakan upaya yang dipilih oleh pemerintah untuk dilakukan atau tidak dilakukan yang berupa sasaran atau tujuan program-program pemerintah. Menurut Friedrich (1963) kebijakan publik sebagai serangkaian tindakan yang diusulkan seseorang, kelompok atau pemerintah dalam suatu lingkungan tertentu, dengan ancaman dan peluang yang ada. Implementasi kebijakan pada prinsipnya adalah cara agar sebuah kebijakan dapat mencapai tujuannya. Untuk mengimplementasikan kebijakan publik terdapat dua pilihan langkah, yaitu langsung mengimplementasikan dalam bentuk program atau melalui formulasi kebijakan turunan dari kebijakan publik tersebut.

Hagen et al. (1996) berpendapat bahwa hubungan keagenan antara pemilih (voters) dengan legislatif pada dasarnya menunjukkan bagaimana voters memilih politisi untuk membuat kebijakan publik bagi mereka dan mereka memberikan dana dengan membayar pajak. Hubungan keagenan ini dapat mempengaruhi perilaku legeslatif dalam membuat kebijakan. Yandra (2011) mengemukakan bahwa penyebab ketidakkonsistenan antara dokumen PPAS dan APBD, di antaranya yaitu kebijakan pemerintah tentang pelaksanaan sebuah program. Hipotesis yang dapat dirumuskan berdasarkan uraian tersebut adalah sebagai berikut:

H4: Terdapat pengaruh kebijakan publik terhadap sinkronisasi dokumen APBD dengan dokumen KUA-PPAS.

\section{Transparansi Publik}

Transparansi bermakna tersedianya informasi yang cukup, akurat dan tepat waktu tentang kebijakan publik, dan proses pembentukannya. Dengan ketersediaan informasi, masyarakat dapat ikut sekaligus mengawasi sehingga kebijakan publik yang muncul bisa memberikan hasil yang optimal bagi masyarakat, serta mencegah terjadinya kecurangan dan manipulasi. Teori Keagenan berfokus pada persoalan asimetri informasi: agen mempunyai informasi lebih banyak tentang kinerja aktual, motivasi, dan tujuannya yang sesungguhnya, yang berpotensi menciptakan moral hazard dan adverse selection (Halim dan Abdullah, 2006). Prinsipal sendiri harus mengeluarkan biaya (costs) untuk memonitor kinerja agen dan menentukan struktur insentif dan monitoring yang efisien (Petrie, 2002). Adanya asimetri informasi di antara eksekutif-legislatif dan legislatif-pemilih menyebabkan terbukanya ruang bagi terjadinya perilaku oportunistik dalam proses penyusunan anggaran, yang justru lebih besar daripada di dunia bisnis yang memiliki automatic checks berupa persaingan (Kasper dan Streit, 1999).

Sopanah dan Mardiasmo (2003) mensyaratkan bahwa anggaran yang disusun oleh pihak eksekutif dikatakan transparan jika memenuhi kriteria berikut: 1) terdapat pengumuman kebijakan anggaran; 2) tersedia dokumen anggaran dan mudah diakses; 3) tersedia laporan pertanggungjawaban yang tepat waktu; 4) terakomodasinya suara/usulan masyarakat; dan 5) terdapat sistem pemberian informasi kepada publik. Elfrina et al. (2014) mengemukakan bahwa interaksi kapasitas sumber dava manusia, perencanaan anggaran, dan politik penganggaran berpengaruh positif terhadap sinkronisasi dokumen dengan transparansi publik sebagai variabel moderasi. Uraian di atas jika ditelaah lebih lanjut, dapat diduga bahwa transparansi publik memoderasi pengaruh kapasitas sumber daya manusia terhadap sinkronisasi dokumen APBD dengan dokumen KUA-PPAS. Kapasitas sumber daya manusia yang memadai dalam proses perencanaan dan penganggaran 
sektor publik dapat menjamin kesinambungan antara perencanaan dan penganggaran, sehingga dengan adanya kesinambungan ini ditambah dengan keterbukaan kepada publik maka proses penyusunan APBD akan semakin berkualitas. Hipotesis yang dapat dirumuskan berdasarkan uraian tersebut adalah sebagai berikut:

H5: Transparansi publik memoderasi pengaruh kappasitas sumber daya manusia terhadap sinkronisasi dokumen APBD dengan dokumen KUA-PPAS.

Perencanaan yang konsisten dengan proses penganggaran akan menciptakan suatu sistem perencanaan penganggaran yang sistematis dan berkelanjutan. Apabila hal tersebut disertai dengan keterbukaan pemerintah dalam perencanaan keuangan daerah, maka dapat dikatakan hasil dari proses penyusunan APBD akan menjadi semakin berkualitas. Hipotesis yang dapat dirumuskan berdasarkan uraian tersebut adalah sebagai berikut:

H6: Transparansi publik memoderasi pengaruh perencanaan anggaran terhadap sinkronisasi dokumen APBD dengan dokumen KUAPPAS.

Keterlibatan legislatif sebagai wakil rakyat dalam proses penyusunan anggaran di sektor publik tidak dapat dihindari lagi. Di samping itu, dengan adanya transparansi publik maka akan memperkuat fungsi pengawasan yang dilakukan oleh dewan sebagai wakil rakyat, sehingga dengan kuatnya pengawasan yang dilakukan oleh dewan maka proses penyusunan APBD akan semakin berkualitas. Hipotesis yang dapat dirumuskan berdasarkan uraian tersebut adalah sebagai berikut:

H7: Transparansi publik memoderasi pengaruh politik penganggaran terhadap sinkronisasi dokumen APBD dengan dokumen KUAPPAS.

Segala bentuk kebijakan publik yang dibuat oleh pemerintah selaku eksekutif bertujuan untuk melindungi kepentingan publik, mengatasi masalah publik, memberdaya publik, dan menciptakan kesejahteraan publik. Dengan adanya keterbukaan pemerintah dalam membuat kebijakan, khususnya keuangan daerah, maka dapat dikatakan hasil dari proses penyusunan anggaran akan dapat mencapai tujuan yang diharapkan. Hipotesis yang dapat dirumuskan berdasarkan uraian tersebut adalah sebagai berikut:
H8: Transparansi publik memoderasi pengaruh kebijakan publik terhadap sinkronisasi dokumen APBD dengan dokumen KUA-PPAS.

\section{METODE PENELITIAN}

\section{Jenis Penelitian, Model Penelitian, Populasi dan Sampel}

Jenis penelitian ini adalah penelitian asosiatif, yaitu penelitian yang mencari hubungan antara satu variabel dengan variabel yang lain, yang di dalam penelitian ini menggunakan hubungan kausal. Hubungan kausal adalah hubungan yang bersifat sebab akibat, dimana terdapat variabel independen (variabel yang mempengaruhi) dan variable dependen (dipengaruhi) (Sugiyono, 2013). Model Penelitian yang menggambarkan keterkaitan antara variabel dalam penelitian ini dapat disajikan dalam Gambar 1.

Populasi dalam penelitian ini adalah anggota dewan yang membidangi pengawasan keuangan daerah dan pejabat/pegawai yang terlibat dalam penyusunan RKA-SKPD pada Pemerintah Kota Mataram. Penentuan sampel pada penelitian ini menggunakan Teknik Purposive Sampling, yang didasarkan pada pertimbangan-pertimbangan: (1) Anggota DPRD yang membidangi pengawasan keuangan daerah (Bidang Keuangan/Anggaran); (2) Pegawai Setda yang terdiri dari 10 bagian; dan (3) Pegawai SKPD yang meliputi pejabat serta staf yang terlibat dalam penyusunan RKA-SKPD, sehingga total jumlah sampel dari 31 SKPD yang dijadikan sampel adalah 122 orang.

\section{Variabel dan Pengukurannya}

Definisi operasi variabel dan pengukurannya dijabarkan sebagai berikut:

(1) Kapasitas Sumber Daya Manusia (X1) yang menjadi variabel independen pertama, merupakan kemampuan dari anggota eksekutif maupun legislatif dalam menjalankan fungsi dan perannya masing-masing dalam proses penyusunan kebijakan dalam pengelolaan keuangan daerah (Iskandar, 2013).

(2) Variabel Perencanaan Anggaran (X2) yang menjadi variabel independen kedua, merupakan cara organisasi menetapkan tujuan dan sasaran organisasi. Perencanaan meliputi aktivitas yang sifatnya strategis, taktis, dan melibatkan aspek operasional. Proses perenca- 


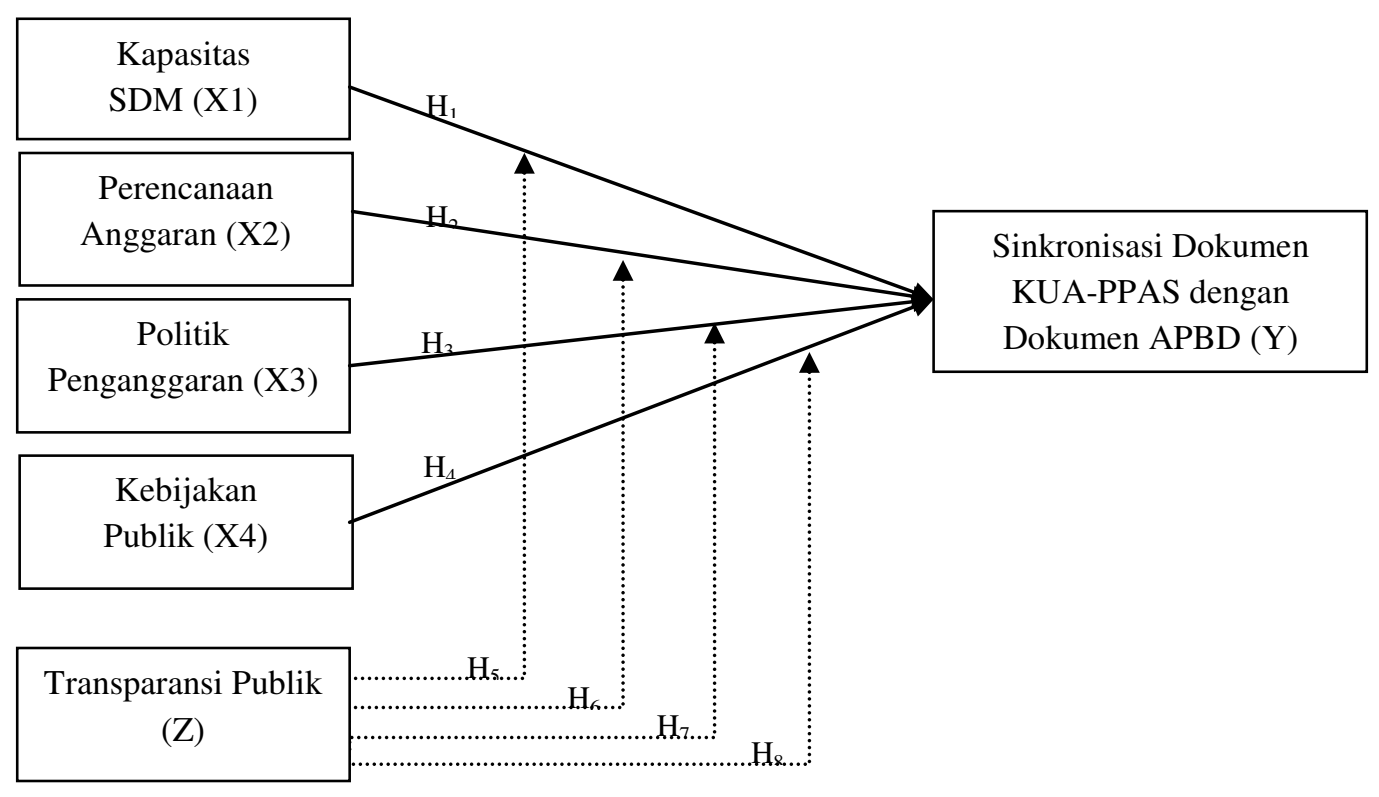

\section{Gambar 1. Model Penelitian}

naan juga melibatkan aspek perilaku, yaitu partisipasi dalam pengembangan sistem perencanaan, penetapan tujuan, dan pemilihan alat yang paling tepat untuk memonitor perkembangan pencapaian tujuan (Iskandar, 2013). Variabel Politik Penganggaran (X3) yang menjadi variabel independen ketiga, adalah cara bagaimana mencapai tujuan yang bersifat kolektif dan mengikat melalui kekuasaan, pengambilan keputusan, kebijakan publik, alokasi dan distribusi dalam proses penerjemahan rencana aktivitas ke dalam rencana keuangan (Iskandar, 2013).

(3) Variabel Kebijakan Publik (X4) yang menjadi variabel independen keempat, merupakan upaya yang dipilih oleh pemerintah untuk dilakukan atau tidak dilakukan yang berupa sasaran atau tujuan program-program pemerintah. Suatu kebijakan dapat dikatakan sebagai kebijakan publik atau tidak, dilihat dari komponen public policynya (Jones, 1984).

(4) Transparansi Publik (Z) merupakan Variabel Moderasi dalam penelitian ini. Transparansi publik merupakan salah satu prinsip good governance. Transparansi dibangun atas dasar arus informasi yang bebas, seluruh proses pemerintahan, lembaga-lembaga dan informasi perlu dapat diakses oleh pihak-pihak yang berkepentingan, dan informasi yang tersedia harus memadai agar dapat dimengerti dan dipantau (Iskandar, 2013).

Masing-masing variabel diukur dengan Skala Likert, yakni skala yang digunaka untuk mengukur sikap dengan menyatakan setuju atau ketidaksetujuan responden terhadap pernyataan yang diajukan dengan skor 5 poin. Instrumen pengukuran Variabel Kapasitas Sumber Daya Manusia, Perencanaan Anggaran, dan Politik Penganggaran serta Sinkronisasi Dokumen APBD dengan Dokumen KUA-PPAS, diadopsi dari penelitian Iskandar (2013). Instrumen pengukuran Variabel Kebijakan Publik diambil dari teori yang dikemukakan oleh Jones (1984). Sedangkan instrumen pengukuran Variabel Transparansi Publik diadopsi dari penelitian Iskandar (2013).

\section{Analisis Data}

Metode analisis data yang digunakan pada penelitian ini adalah Analisis Regresi Linier Berganda untuk hipotesis pertama, kedua, ketiga dan keempat. Persamaan regresi linier berganda untuk hipotesis pertama hingga keempat adalah sebagai berikut:

$$
\mathrm{Y}=\alpha+\mathrm{b} 1 \mathrm{X} 1+\mathrm{b} 2 \mathrm{X} 2+\mathrm{b} 3 \mathrm{X} 3+\mathrm{b} 4 \mathrm{X} 4+\mathrm{e}
$$

Pengujian hipotesis kelima, keenam, ketujuh dan kedelapan dengan Variabel Moderasi dilaku- 
kan dengan Metode Interaksi (Moderated Regression Analysis - MIRA). Persamaan regresi linier berganda untuk hipotesis kelima hingga kedelapan adalah sebagai berikut:

$\mathrm{Y}=\alpha+\mathrm{b}_{1} \mathrm{X}_{1}+\mathrm{b}_{2} \mathrm{X}_{2}+\mathrm{b}_{3} \mathrm{X}_{3}+\mathrm{b}_{4} \mathrm{X}_{4}+\mathrm{b}_{5} \mathrm{Z}+\mathrm{b}_{6} \mathrm{X}_{1} \mathrm{Z}+$ $\mathrm{b}_{7} \mathrm{X}_{2} \mathrm{Z}+\mathrm{b}_{8} \mathrm{X}_{3} \mathrm{Z}+\mathrm{b}_{9} \mathrm{X}_{4} \mathrm{Z}+\mathrm{e}$

Keterangan:

$\mathrm{Y}=$ Sinkronisasi Dokumen APBD dengan Dokumen KUA-PPAS

$\mathrm{X}_{1}=$ Kapasitas Sumber Daya Manusia

$\mathrm{X}_{2}=$ Perencanaan Anggaran

$\mathrm{X}_{3}=$ Politik Penganggaran

$\mathrm{X}_{4}=$ Kebijakan Publik

$\mathrm{Z}=$ Transparansi Publik

$\alpha=$ Konstanta

$\mathrm{b}=$ Koefisien Regresi

$\mathrm{e}=$ Error

\section{HASIL DAN PEMBAHASAN}

\section{Pengujian Validitas dan Reliabilitas Data}

Hasil uji validitas diketahui bahwa seluruh item pernyataan variabel kapasitas sumber daya manusia (KSDM), perencanaan anggaraan (PA), politik penganggaran (PP), kebijakan publik (KP), transparansi publik (TP), dan sinkonisasi dokumen (SD) mempunyai tingkat signifikansi $<0,05$ dengan nilai kolerasi ( $\mathrm{r}$ ) yang lebih besar dari titik kritis yaitu 0,30 atau bernilai positif, yang artinya semua butir pernyataan dapat dikatakan valid. Hasil pengujian validitas menunjukkan bahwa indikator yang disusun oleh peneliti dapat di- gunakan dalam penelitian selanjutnya dengan variabel yang sama.

Hasil uji reliabilitas data diketahui nilai koefisien Cronbach Alpha variabel penelitian berkisar antara 0,613 sampai dengan 0,757. Hasil pengujian reliabilitas menunjukkan bahwa enam variabel yang digunakan dalam penelitian ini memiliki $\alpha$ mendekati 1,00 dan lebih dari 0,6, maka dapat dikatakan bahwa atribut-atribut variabel mendapatkan kriteria reliabel (andal) secara statistikk (Sofyani dan Akbar, 2013; 2015). Hasil pengujian reliabilitas menunjukkan bahwa indikator yang disusun untuk mengukur keenam variabel yang digunakan dalam penelitian ini dapat juga digunakan untuk mengukur variabel yang sama dalam penelitian dengan subjek yang berbeda.

\section{Pengujian Asumsi Klasik}

Uji asumsi klasik ini terdiri dari pengujian normalitas, multikolinearitas, dan heteroskedastisitas. Hasil uji normalitas data dengan menggunakan uji statistik non-parametrik KolmogorovSmirnov (K-S) maka diketahui bahwa data berdistribusi normal, terlihat dari nilai Probability Sig (2 tailed) 0. 934 lebih dari $\alpha$ 0,05. Hasil uji multikolinearitas diketahui tidak ditemukan adanya multikolinearitas antar variabel independen karena nilai Variance Inflation Factor (VIF) kurang dari 10 dan nilai toleransi lebih dari 0,10. Hasil Uji Glejser melihat nilai signifikansi untuk setiap variabel independen yang lebih dari $\alpha 0,05$, dengan demikian dapat disimpulkan bahwa tidak terjadi heteroskedastisitas.

Tabel 1. Hasil Uji Hipotesis t (Parsial) Hipotesis Pertama hingga Keempat

\begin{tabular}{|c|c|c|c|c|c|}
\hline & \multicolumn{2}{|c|}{ Unstandardized Coefficients } & \multirow{2}{*}{$\begin{array}{c}\begin{array}{c}\text { Standardized } \\
\text { Coefficients }\end{array} \\
\text { Beta }\end{array}$} & \multirow[b]{2}{*}{$t$} & \multirow[b]{2}{*}{ Sig. } \\
\hline & $B$ & Std. Error & & & \\
\hline (Constant) & 10.632 & 3.530 & & 3.012 & .003 \\
\hline KSDM & .103 & .093 & .127 & 3.099 & .007 \\
\hline PA & .156 & .069 & .206 & 2.242 & .017 \\
\hline PP & .118 & .037 & .282 & 3.195 & .002 \\
\hline $\mathrm{KP}$ & .136 & .093 & .160 & 1.457 & .148 \\
\hline TP & 298 & .070 & .388 & 4.272 & .000 \\
\hline R Square & & & & & .340 \\
\hline Adjusted R Square & & & & & .305 \\
\hline
\end{tabular}


Tabel 2. Hasil Uji t Sebelum Variabel Ditransformasikan dalam Bentuk Logaritma Natural

\begin{tabular}{|c|c|c|c|c|c|c|c|}
\hline & Unstandardize & Coefficients & $\begin{array}{c}\text { Standardized } \\
\text { Coefficients }\end{array}$ & & & Collinearit & Statistics \\
\hline & $B$ & Std. Error & Beta & $t$ & Sig. & Tolerance & $V I F$ \\
\hline (Constant) & 22.773 & 24.521 & & .929 & .355 & & \\
\hline KSDM & -.290 & .771 & -.359 & -.375 & .708 & .007 & 138.237 \\
\hline PA & -1.020 & .494 & -1.348 & -2.065 & .042 & .016 & 64.256 \\
\hline PP & .280 & .280 & .668 & .998 & .321 & .015 & 67.646 \\
\hline $\mathrm{KP}$ & 1.056 & .867 & 1.242 & 1.218 & .226 & .006 & 156.930 \\
\hline TP & -.292 & 1.210 & -.380 & -.241 & .810 & .003 & 375.479 \\
\hline Interaksi_1 & .010 & .038 & .547 & .254 & .800 & .001 & 701.653 \\
\hline Interaksi_2 & .044 & .024 & 2.605 & 1.795 & .076 & .003 & 317.794 \\
\hline Interaksi_3 & -.008 & .013 & -.704 & -.600 & .550 & .005 & 207.953 \\
\hline Interaksi_4 & -.048 & .043 & -1.719 & -1.106 & .272 & .003 & 364.731 \\
\hline
\end{tabular}

Tabel 3. Hasil Uji t Setelah Variabel Ditransformasikan dalam Bentuk Logaritma Natural

\begin{tabular}{|c|c|c|c|c|c|c|c|}
\hline & \multicolumn{2}{|c|}{$\begin{array}{c}\text { Unstandardized } \\
\text { Coefficients }\end{array}$} & \multirow{2}{*}{$\begin{array}{c}\begin{array}{c}\text { Standardized } \\
\text { Coefficients }\end{array} \\
\text { Beta }\end{array}$} & \multirow[b]{2}{*}{$t$} & \multirow[b]{2}{*}{ Sig. } & \multicolumn{2}{|c|}{ Collinearity Statistics } \\
\hline & $B$ & Std. Error & & & & Tolerance & $V I F$ \\
\hline (Constant) & 5.890 & 12.192 & & .483 & .630 & & \\
\hline LNKSDM & -3.659 & 3.496 & -.124 & -1.047 & .298 & .503 & 1.986 \\
\hline LNPA & -5.904 & 2.625 & -.209 & -2.249 & .027 & .812 & 1.231 \\
\hline LNPP & 4.683 & 1.519 & .270 & 3.082 & .003 & .914 & 1.094 \\
\hline LNKP & -3.025 & 2.365 & -.155 & -1.279 & .204 & .480 & 2.083 \\
\hline LNInteraksi_4 & 5.852 & 1.334 & .476 & 4.388 & .000 & .598 & 1.672 \\
\hline
\end{tabular}

\section{Pengujian Hipotesis Satu hingga Empat}

Pengujian hipotesis pertama hingga keempat dalam penelitian ini menggunakan persamaan sebagai berikut:

$\mathrm{Y}=\alpha+\mathrm{b} 1 \mathrm{X} 1+\mathrm{b} 2 \mathrm{X} 2+\mathrm{b} 3 \mathrm{X} 3+\mathrm{b} 4 \mathrm{X} 4+\mathrm{e}$.

Hasil Pengujian Koefisien Determinasi $\left(\mathbf{R}^{2}\right)$ diperoleh nilai sebesar 0,305 berarti variabel independen (Sinkronisasi Dokumen APBD dengan Dokumen KUA-PPAS) mampu menjelaskan variasi variabel dependen (kapasitas sumber daya manusia, perencanaan anggaran, politik penganggaran dan kebijakan publik) hanya sebesar $30 \%$, dan sisanya sebesar $70 \%$ dijelaskan oleh variabel-variabel lain di luar model penelitian (lihat Tabel 1).

\section{Pengujian Hipotesis Lima hingga Delapan}

Dari hasil Pengujian Koefisien Determinasi $\left(\mathbf{R}^{2}\right)$ diperoleh nilai sebesar 0,331 yang berarti variabel independen mampu menjelaskan variasi variabel dependen hanya sebesar $33 \%$, sisanya sebesar $67 \%$ diterangkan oleh variabel lain di luar model.

\section{Hasil Pengujian Pengaruh Variabel Independen}

Untuk mengetahui pengaruh variabel kapasitas sumber daya manusia terhadap sinkronisasi dokumen APBD dengan dokumen KUA-PPAS, maka dapat dilihat dari hasil nilai t hitung dan signifikansi nilai $\mathrm{t}$ hitung tersebut. Hasil uji $\mathrm{t}$ diperoleh pengaruh kapasitas sumber daya manusia terhadap sinkronisasi dokumen APBD dengan dokumen KUA-PPAS positif dan signifikan. Hal ini dapat dilihat dari nilai koefisien regresi sebesar 0,103 dan nilai t hitung $(2,099)>\mathrm{t}$ tabel $(1,985)$ dengan nilai signifikansi $0,007<\alpha 0,05$.

Hasil penelitian ini sejalan dengan penelitian Elfrina et al. (2014) dan Hikmah (2015) yang menemukan kapasitas sumber daya manusia berpengaruh positif signifikan terhadap sinkronisasi Dokumen APBD dengan Dokumen KUAPPAS. Pengaruh positif menandakan jika aparatur pemerintahan profesional dan kompeten dalam 
menyusun Rencana Kerja dan Anggaran Satuan Kerja Perangkat Daerah (RKA-SKPD) akan berdampak positif terhadap sinkronisasi dokumen APBD dengan dokumen KUA-PPAS. Pengaruh signifikan menunjukkan bahwa kualitas dan kapasitas sumber daya manusia mempunyai peranan sangat penting dalam meningkatkan sinkronisasi dokumen APBD dengan dokumen KUA-PPAS.

Hasil uji t menunjukkan pengaruh variabel perencanaan anggaran terhadap sinkronisasi dokumen APBD dengan dokumen KUA-PPAS positif dan signifikan. Hal tersebut dapat dilihat dari nilai koefisien regresi sebesar 0,156 dengan nilai signifikansi $0,027\langle\alpha 0,05$ dan nilai t hitung $(2,242)>$ nilai t tabel $(1,985)$, ini berarti bahwa perencanaan anggaran yang dilakukan oleh eksekutif dan legislatif berpengaruh positif dan signifikan terhadap sinkronisasi dokumen APBD dengan dokumen KUA-PPAS. Dengan kata lain, perencanaan anggaran yang baik mampu menyinkronkan dokumen APBD dengan dokumen KUAPPAS.

Hasil penelitian ini sejalan dengan penelitian Elfrina (2014) dan penelitian Hikmah (2015) yang menemukan perencanaan anggaran berpengaruh positif signifikan terhadap sinkronisasi Dokumen APBD dengan Dokumen KUA-PPAS. Dari temuan ini dapat disimpulkan bahwa semakin baik perencanaan anggaran yang dilakukan maka akan semakin meningkatkan sinkronisasi Dokumen APBD dengan Dokumen KUA-PPAS. Apabila tahap perencanaan anggaran dilakukan secara baik maka akan berdampak baik pula pada proses penganggaran selanjutnya.

Pengaruh positif ini diduga karena pemerintah daerah dan DPRD telah memiliki komitmen yang tinggi dalam proses perencanaan dan penganggaran sebagaimana yang diamanatkan dalam Permendagri 37/2014 tentang Pedoman Penyusunan APBD Tahun Anggaran 2015 yang menghendaki bahwa dalam menyusun Kebijakan Umum APBD (KUA) dan rancangan Prioritas dan Plafon Anggaran Sementara (PPAS) Pemerintah Kabupaten/Kota harus berpedoman pada Rencana Kerja Pemerintah Daerah (RKPD) Kabupaten/ Kota.

Hasil uji t menunjukkan pengaruh politik penganggaran terhadap sinkronisasi dokumen APBD dengan dokumen KUA-PPAS adalah positif dan signifikan. Hal tersebut dapat diketahui dari nilai koefisien regresi sebesar 0,118 dan nilai $t$ hitung $(3,195)>t$ tabel $(1,985)$ dengan nilai signifikansi $0,002<\alpha 0,05$ bermakna bahwa politik penganggaran berpengaruh positif signifikan ter- hadap sinkronisasi dokumen APBD dengan dokumen KUA-PPAS. Hasil penelitian ini sejalan dengan pendapat Amirudin (2006) yang menemukan peran utama legislatif dalam proses politik penyusunan ABPD terlihat jelas saat pembahasan KUA-PPAS serta dalam penetapan Perda APBD. Hasil penelitian juga sejalan dengan penelitian Iskandar (2013), Elfrina (2014) dan Hikmah (2015) yang menemuka politik penganggaran berpengaruh positif signifikan terhadap sinkronisasi Dokumen APBD dengan Dokumen KUA-PPAS.

Dari hasil ini maka dapat disimpulkan bahwa politik penganggaran mempunyai peranan sangat penting dalam meningkatkan sinkronisasi dokumen APBD dengan dokumen KUA-PPAS. Akibat yang ditimbulkan dari penerapan teori keagenan dalam politik penganggaran dapat menimbulkan hal positif dalam bentuk efisiensi. Namun perlu pula untuk menjadi catatan bahwa politik penganggaran juga dapat memunculkan dampak negative berupa munculnya perilaku opportunistik.

Hasil uji t menunjukkan pengaruh Kebijakan Publik terhadap Sinkronisasi Dokumen APBD dengan Dokumen KUA-PPAS adalah tidak signifikan, dengan kata lain Kebijakan Publik tidak berpengaruh terhadap Sinkronisasi Dokumen APBD dengan Dokumen KUA-PPAS. Hal tersebut dapat diketahui dari nilai koefisien regresi sebesar 0,136 dan nilai $\mathrm{t}$ hitung $(1,457)<\mathrm{t}$ tabel $(1,985)$ dengan nilai signifikansi $0,148>\alpha 0,05$. Ketidaksignifikanan ini diduga karena kebijakan penganggaran yang berasal dari pemerintah pusat dalam bentuk Dana Alokasi Khusus (DAK) kepada satuan kerja perangkat daerah (SKPD) tertentu, tidak mempengaruhi Sinkronisasi Dokumen KUA-PPAS dan Dokumen APBD secara signifikan dan keseluruhan, yang artinya hanya berdampak pada Sinkronisasi Dokumen PPAS dan Dokumen Pelaksanaan Anggaran SKPD yang bersangkutan saja.

\section{Hasil Pengujian Pengaruh Variabel Pemoderasi}

Pada hasil pengujian hipotesis kelima hingga kedelapan menunjukkan hasil dimana terdapat adanya korelasi antar variabel independen yang berarti terjadi multikolinieritas antar variabel independen. Salah satu cara untuk mengurangi hubungan linier antar variabel independen yaitu dengan transformasi variabel dalam bentuk logaritma natural, sehingga output yang dihasilkan tidak terjadi multikolinieritas (Ghozali, 2013). Dari hasil 
pengujian variabel dalam bentuk logaritma natural yang telah ditransformasikan, hanya 5 variabel yang tersisa yaitu LNKSDM, LNPA, LNPP, LNKP dan LNInteraksi_4, sedangkan 4 variabel lainnya yaitu LNTP, LNInte-raksi_1, LNInteraksi_2, dan LNInteraksi_3 dikeluarkan untuk menghasilkan data yang normal tanpa ada korelasi antar variabel independen.

Berdasarkan hasil analisis pada Tabel Uji t setelah variabel ditransformasikan dalam bentuk logaritma natural, diketahui bahwa logaritma natural variabel Transparansi Publik (LNTP) yang dihipotesiskan sebagai variabel pemoderasi, termasuk ke dalam kategori variabel yang dikeluarkan setelah Variabel ditransformasikan dalam bentuk Logaritma Natural. Dengan demikian, untuk pengujian interaksi tidak dapat dilanjutkan walaupun terdapat hasil uji interaksi Variabel Kebijakan Publik dengan Transparansi Publik (LNInteraksi_4) dengan nilai signifikansi (sig.) 0,000 yang lebih kecil daripada nilai alpha $\alpha 0,05$, yang berarti interaksi antara Variabel Kebijakan Publik dengan Variabel Transparansi Publik (LNInteraksi_4) signifikan. Uji t setelah variabel ditransformasikan dalam bentuk logaritma natural menunjukkan hasil bahwa variabel Transparansi Publik (LNTP) yang dihipotesiskan sebagai variabel moderasi ternyata tidak berhasil berperan sebagai variabel moderasi di dalam model. Hasil penelitian ini sejalan dengan penelitian Iskandar (2013) yang menemukan bahwa transparansi publik tidak dapat memoderasi hubungan antara kapasitas sumber daya manusia, perencanaan anggaran dan politik penganggaran terhadap sinkronisasi dokumen APBD dengan dokumen KUA-PPAS.

Hasil penelitian ini menunjukkan bahwa Variabel Transparansi Publik tidak dapat memoderasi hubungan antara Variabel Kapasitas Sumber Daya Manusia, Perencanaan Anggaran dan Politik Penganggaran, dan Kebijakan Publik terhadap Sinkronisasi Dokumen APBD dengan Dokumen KUA-PPAS. Hal ini diduga karena pada Pemerintah Kota Mataram belum memiliki keterbukaan dalam membuat kebijakan-kebijakan keuangan daerah khusunya dalam penyusunan RKA-SKPD, sehingga kebijakan keuangan tersebut tidak dapat diketahui oleh masyarakat. Fenomena tersebut bertentangan dengan Permendagri No. 13 Tahun 2006 tentang Pedoman Pengelolaan Keuangan Daerah yang mengamanatkan kepada pemerintah daerah untuk melakukan sosialisasi Rancangan APBD sebelum disampaikan kepada DPRD dan masyarakat karena
APBD merupakan dokumen public, dimana masyarakat memiliki hak untuk mengetahui informasi di dalamnya. Hak masyarakat untuk mengakses dokumen-dokumen publik ini dijamin oleh UU No. 14 Tahun 2008 tentang Keterbukaan Informasi Publik. Hasil penelitian ini juga tidak sejalan dengan pendapat Sopanah dan Mardiasmo (2003) yang mensyaratkan bahwa anggaran yang disusun oleh pihak eksekutif dikatakan transparansi jika memenuhi kriteria berikut: 1) Terdapat pengumuman kebijakan anggaran; 2) Tersedia dokumen anggaran dan mudah diakses; 3) Tersedia laporan pertanggungjawaban yang tepat waktu; 4) Terakomodasinya suara/usulan masyarakat; dan 5) Terdapat sistem pemberian informasi kepada publik.

\section{SIMPULAN}

Dari hasil pengujian statistik dapat disimpulkan bahwa Kapasitas Sumber Daya Manusia, Perencanaan Anggaran Dan Politik Penganggaran berpengaruh positif signifikan terhadap Sinkronisasi Dokumen APBD dengan Dokumen KUAPPAS. Sedangkan Kebijakan Publik tidak berpengaruh terhadap Sinkronisasi Dokumen APBD dengan Dokumen KUA-PPAS. Hasil uji interaksi menunjukkan bahwa Transparansi Publik gagal memoderasi hubungan antara Kapasitas Sumber Daya Manusia, Perencanaan Anggaran, Politik Penganggaran dan Kebijakan Publik terhadap Sinkronisasi Dokumen APBD dengan Dokumen KUA-PPAS.

Secara teoritis implikasi dari temuan penelitian ini dapat memberikan penjelasan atas konsep dasar sinkronisasi dalam proses penyusunan dokumen perencanaan dan penganggaran, yang di dalamnya melibatkan pihak eksekutif dan legislatif, dan masyarakat. Secara praktis hasil penelitian ini dapat memberikan manfaat dalam praktik perencanaan dan penganggaran di Pemerintah Kota Mataram, terutama dalam hal keterkaitan antar dokumen pada setiap tahapan perencanaan. Implikasi penelitian ini berupa masukkan dan pertimbangan bagi lembaga eksekutif dan lembaga legislatif, dalam menentukan kebijakan yang berhubungan dengan sinkronisasi dokumen APBD dengan dokumen KUA-PPAS.

Penelitian ini memiliki keterbatasan, diantaranya ruang lingkup wilayah penelitian ini hanya terbatas pada satu kota saja, yaitu Kota Mataram dengan jumlah sampel yang juga terbatas, sehingga tingkat generalisasi dari penelitian masih kurang. 
Sinkronisasi dokumen APBD dengan dokumen KUA-PPAS dalam penelitian ini hanya diukur dari kapasitas sumber daya manusia, perencanaan anggaran, politik penganggaran dan kebijakan publik, serta transparansi publik sebagai variabel moderasi. Berdasarkan keterbatasan penelitian tersebut, maka untuk penelitian selanjutnya peneliti menyarankan agar menambahkan jumlah responden dan memperluas ruang lingkup wilayah hingga ke kabupaten/kota lainnya sehingga memungkinkan untuk diperoleh hasil temuan, kesimpulan serta rekomendasi dengan tingkat generalisasi yang lebih tinggi.

Selain itu, penelitian selanjutnya disarankan pula agar menambahkan variabel-variabel lainnya yang dapat mempengaruhi sinkronisasi dokumen APBD dengan dokumen KUA-PPAS, seperti variabel capaian kinerja, perilaku oportunistik, dan informasi pendukung. Serta mencari variabel moderasi lain yang dapat memoderasi hubungan antara kapasitas sumber daya manusia, perencanaan anggaran, politik penganggaran dan kebijakan publik terhadap sinkronisasi dokumen APBD dengan dokumen KUA-PPAS, seperti variabel partisipasi publik.

\section{DAFTAR PUSTAKA}

Agustino, L. 2012. Dasar-Dasar Kebijakan Publik. Bandung: Alfabeta.

Amirudin. 2009. Identifikasi dan Analisis FaktorFaktor yang Mempengaruhi Sinkronisasi Dokumen Anggaran Pendapatan dan Belanja Daerah dengan Dokumen Kebijakan Umum Anggaran dan Prioritas Plafon Anggaran Sementara: Studi Kasus Provinsi D.I. Yogyakarta TA 2008. Tesis, Universitas Gadjah Mada.

Dye, T. R. 1978. Understanding Public Policy. New Jersey: Prentice Hall.

Edward III, George C. 1980. Implementing Public Policy. Congressional Quarterly Press: Washington DC.

Elfrina, L., V. Ratnawati dan M. Wiguna. 2014. Pengaruh Kapasitas Sumber Daya Manusia, Perencanaan Penganggaran, Politik Pengaggaran, dan Informasi Pendukung dengan Transparasi Publik sebagai Variabel Moderasi terhadap Sinkronisasi Dokumen APBD dengan Dokumen KUA-PPAS (Studi Empiris pada SKPD Kabupaten Lingga). JOM FEKON, 1 (2).
Friedrich, C. J. 1963. Man and His Government. New York: McGraw-Hill.

Ghozali, I. 2013. Aplikasi Analisis Multivariate Dengan Program IBM SPSS 21. Semarang: Badan Penerbit Universitas Diponegoro.

Gilardi, F. 2001. Principal-Agent Models Go To Europe: Independent Regulatory Agencies As Ultimate Step of Delegation. Paper presented at the ECPR General Conference, Canterbury (UK), 6-8 September 2001.

Hagen, T. P., R. J. Sorensen dan O. Norly. 1996. Bargaining Strength In Budgetary Process: The Impact of Institutional Procedures. Journal of Theoretical Politics.

Halim, A. dan S. Abdullah. 2006. Hubungan dan Masalah Keagenan di Pemerintah Daerah: Sebuah Peluang Penelitian Anggaran dan Akuntansi. Jurnal Akuntansi Pemerintah, 2 (1), 53-64.

Hikmah, N. 2015. Pengaruh Kapasitas Sumber Daya Manusia, Perencanaan Anggaran, Politik Penganggaran, Dan Transparansi Publik Terhadap Sinkronisasi Dokumen APBD Dengan KUA-PPAS Pada Pemerintah Kabupaten Lombok Barat. Tesis. Universitas Mataram.

Iskandar, D. 2013. Pengaruh Kapasitas Sumber Daya Manusia, Perencanaan Penganggaran, Politik Penganggaran dengan Transparansi Publik sebagai Variabel Moderasi Terhadap Sinkronisasi Dokumen APBD dengan Dokumen KUA-PPAS. Tesis, Universitas Sumatera Utara.

Jensen, M. C. dan W. H. Meckling. 1976. Theory of the Firm: Managerial Behavior, Agency Costs and Ownership Structure. Journal of Financial Economics, 3 (4), 305-360.

Jones, C. O. 1984. An Introduction to the Study of Public Policy. 3rd Edition.: Salt Lake City, Utah: Brooks/Cole Pub Co.

Kasper, W dan M. E. Streit. 2001. Institutional Economics: Social Order and Public Policy. Cheltham: Edward Elgar.

Messier, W. F., S. M. Glover dan D. F. Prawitt. 2006. Auditing and Assurance Services: A Systematic Approach. 6th Edition. New York: Irwin/McGraw-Hill.

Moe, T. M. 1984. The New Economics Of Organization. American Journal of Political Science, 28 (5), 739-777.

Mursyidi. 2009. Akuntansi Pemerintahan di Indonesia. Refika Aditama: Bandung. 
Petrie, M. 2002. A Framework For Public Sector Performance Contracting. OECD Journal on Budgeting, 117-153.

Rasyid, A. 2012. Analisis Faktor-Faktor yang Mempengaruhi Sinkronisasi Dokumen Rencana Kerja Pemerintah Daerah Dengan Dokumen Anggaran Pendapatan Dan Belanja Daerah. Laporan Penelitian. Universitas Yapis.

Simamora, H. 2001. Manajemen Sumber Daya Manusia. Cetakan 3. Yogyakarta: STIE YKPN.

Sofyani, H., dan R. Akbar. 2013. Hubungan Faktor Internal Institusi dan Implementasi Sistem Akuntabilitas Kinerja Instansi Pemerintah (SAKIP) di Pemerintah Daerah. Jurnal Akuntansi dan Keuangan Indonesia, 10 (2), 184-205.

Sofyani, H. dan R. Akbar. 2015. Hubungan Karakteristik Pegawai Pemerintah Daerah dan Implementasi Sistem Pengukuran Kinerja: Perspektif Ismorfisma Institusional. Jurnal Akuntansi \& Auditing Indonesia, 19 (2), 153-173.

Sopanah dan Mardiasmo. 2003. Pengaruh Partisipasi Masyarakat dan Transparansi Kebijakan Publik Terhadap Hubungan Pengetahuan Antara Pengetahuan Dewan Tentang Anggaran Dengan Pengawasan Keuangan Daerah. Paper Dipresentasikan pada Simposium Nasional Akuntansi VI, Surabaya.

Strom, K. 2000. Delegation And Accountability In Parliamentary Democracies. European Journal of Political Research, 37, 261-289.

Sugiyono. 2013. Metode Penelitian Kuantitatif, $K$ ualitatif dan $R$ dan $D$. Bandung: Alfabeta.

Wiley, J. 2007. Government and Not-for-Profit Accounting: Concepts and Practices. 4th Edition. By Michael H. Granof.

Yandra, F. 2011. Analisis Perencanaan dan Penganggaran Pada Dinas Pekerjaan Umum Kabupaten Solok Tahun 20062010. Skripsi, Universitas Andalas.

Republik Indonesia. 1999. Undang-Undang Nomor 22 tahun 1999 tentang Pemerintahan Daerah.

. 2004. Undang-Undang Nomor 25 tahun 2004 tentang Sistem Perencanaan Pembangunan Nasional.
2004. Undang-Undang Nomor 32 tahun 2004 tentang Pemerintahan Daerah. . 2008 Undang-Undang Nomor 14 tahun 2008 tentang Keterbukaan Informasi Publik.

. 2014 Undang-Undang Nomor 23 tahun 2014 tentang Pemerintahan Daerah. - 2000. Peraturan Pemerintah Nomor 110 tahun 2000 tentang Kedudukan Keuangan Dewan Perwakilan Rakyat Daerah.

. 2005. Peraturan Pemerintah Nomor 58 tahun 2005 tentang Pengelolaan Keuangan Daerah.

. 2007. Peraturan Pemerintah Nomor 39 tahun 2007 tentang Pengelolaan Uang Negara/Daerah.

. 2008 Peraturan Pemerintah Nomor 32 tahun 2008 tentang Pedoman Penyusunan Anggaran Pendapatan Belanja Daerah.

Departemen Dalam Negeri. 2006. Peraturan Menteri Dalam Negeri Nomor 13 tahun 2006 tentang Pedoman Pengelolaan Keuangan Daerah. . 2007. Peraturan Menteri Dalam Negeri Nomor 59 tahun 2007 tentang Perubahan Peraturan Menteri Dalam Negeri Nomor 13 tahun 2006 tentang Pedoman Pengelolaan Keuangan Daerah. . 2011. Peraturan Menteri Dalam Negeri Nomor 21 tahun 2011 tentang Perubahan Kedua Atas Permendagri Nomor 13 Tahun 2006 tentang Pedoman Pengelolaan Keuangan Daerah. . 2011. Peraturan Menteri Dalam Negeri Nomor 22 tahun 2011 tentang Pedoman Penyusunan Anggaran Belanja Daerah Tahun 2012.

Kota Mataram. 2015. Hasil Evaluasi Rancangan Peraturan Daerah tentang Anggaran Pendapatan Dan Belanja Daerah (APBD) Kota Mataram Tahun 2015. - 2015. Kebijakan Umum Anggaran Pendapatan Dan Belanja Daerah Kota Mataram Tahun 2015. 2015. Prioritas dan Plafon Anggaran Sementara Umum Anggaran Pendapatan Dan Belanja Daerah Kota Mataram Tahun 2015. 


\section{LAMPIRAN (KUISIONER)}

\section{Data Responden}

Bapak/Ibu/Saudara/i dimohon untuk mengisi data berikut dan memberi tanda silang $(\mathrm{X})$ atau tanda rumput (V) pada pilihan yang telah disediakan.

Satuan Kerja

Jabatan

Jenis Kelamin

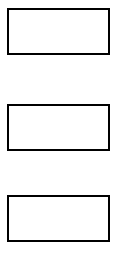

Pria

$\square$ Wanita

Usia

21-30 Tahun

31-40 Tahun

41-50 Tahun

> 50 Tahun

Pendidikan Terakhir :

SMA

Diploma

Masa Kerja

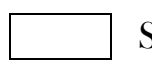

Sarjana

Pascasarjana

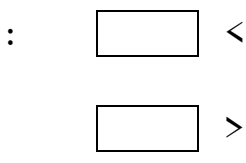

$<5$ tahun

5-10 tahun

\section{Petunjuk Pengisian :}

Bapak/Ibu/Saudara/i dimohon untuk mengisi kuisioner ini dengan memberi tanda silang (X) atau tanda rumput $(\mathrm{V})$ pada pilihan yang telah disediakan, yang menurut Bapak/Ibu/Saudara/i paling sesuai dengan kondisi yang sebenarnya.

\section{Pernyataan Kuesioner Penelitian}

\begin{tabular}{|c|c|c|c|c|c|c|}
\hline \multirow{2}{*}{\multicolumn{2}{|c|}{\begin{tabular}{l|r} 
No. & Pernyataan \\
A. SINKRONISASI
\end{tabular}}} & \multicolumn{5}{|c|}{ Alternatif Jawaban } \\
\hline & & & & & & \\
\hline \multicolumn{2}{|c|}{ Kesesuaian Antar Dokumen } & 5 & 4 & 3 & 2 & 1 \\
\hline \multirow[t]{2}{*}{1.} & \multirow{2}{*}{$\begin{array}{l}\text { Perubahan jumlah anggaran } \\
\text { SKPD mungkin dilakukan } \\
\text { antara dokumen KUA-PPAS } \\
\text { dengan dokumen APBD. } \\
\end{array}$} & $\begin{array}{c}\text { Sangat } \\
\text { mungkin }\end{array}$ & Mungkin & $\begin{array}{l}\text { Kurang } \\
\text { mungkin }\end{array}$ & $\begin{array}{c}\text { Tidak } \\
\text { mungkin }\end{array}$ & $\begin{array}{c}\text { Sangat tidak } \\
\text { mungkin }\end{array}$ \\
\hline & & & & & & \\
\hline \multirow[t]{2}{*}{2.} & \multirow{2}{*}{$\begin{array}{l}\text { Penambahan/pengurangan } \\
\text { program dan kegiatan SKPD } \\
\text { dapat dilakukan antara } \\
\text { dokumen KUA-PPAS } \\
\text { dengan dokumen APBD. }\end{array}$} & $\begin{array}{c}\text { Sangat } \\
\text { mungkin }\end{array}$ & Mungkin & $\begin{array}{c}\text { Kurang } \\
\text { mungkin }\end{array}$ & $\begin{array}{c}\text { Tidak } \\
\text { mungkin }\end{array}$ & $\begin{array}{c}\text { Sangat tidak } \\
\text { mungkin }\end{array}$ \\
\hline & & & & & & \\
\hline \multicolumn{2}{|c|}{ Dasar Pergeseran Anggaran } & 5 & 4 & 3 & 2 & 1 \\
\hline \multirow[t]{2}{*}{3.} & \multirow{2}{*}{$\begin{array}{l}\text { Regulasi mengehendaki } \\
\text { perubahan program dan } \\
\text { kegiatan SKPD antara } \\
\text { dokumen KUA-PPAS } \\
\text { dengan dokumen APBD. }\end{array}$} & Sangat setuju & Setuju & $\begin{array}{c}\text { Kurang } \\
\text { setuju }\end{array}$ & Tidak setuju & $\begin{array}{c}\text { Sangat tidak } \\
\text { setuju }\end{array}$ \\
\hline & & & & & & \\
\hline \multirow[t]{2}{*}{4.} & \multirow{2}{*}{$\begin{array}{l}\text { Dokumen KUA dan PPAS } \\
\text { serta dokumen APBD } \\
\text { disepakati oleh Badan } \\
\text { Anggaran, Tim Anggaran } \\
\text { Pemerintah Daerah (TAPD) } \\
\text { dan Kepala Daerah. }\end{array}$} & Sangat setuju & Setuju & $\begin{array}{c}\text { Kurang } \\
\text { setuju }\end{array}$ & Tidak setuju & $\begin{array}{c}\text { Sangat tidak } \\
\text { setuju }\end{array}$ \\
\hline & & & & & & \\
\hline
\end{tabular}




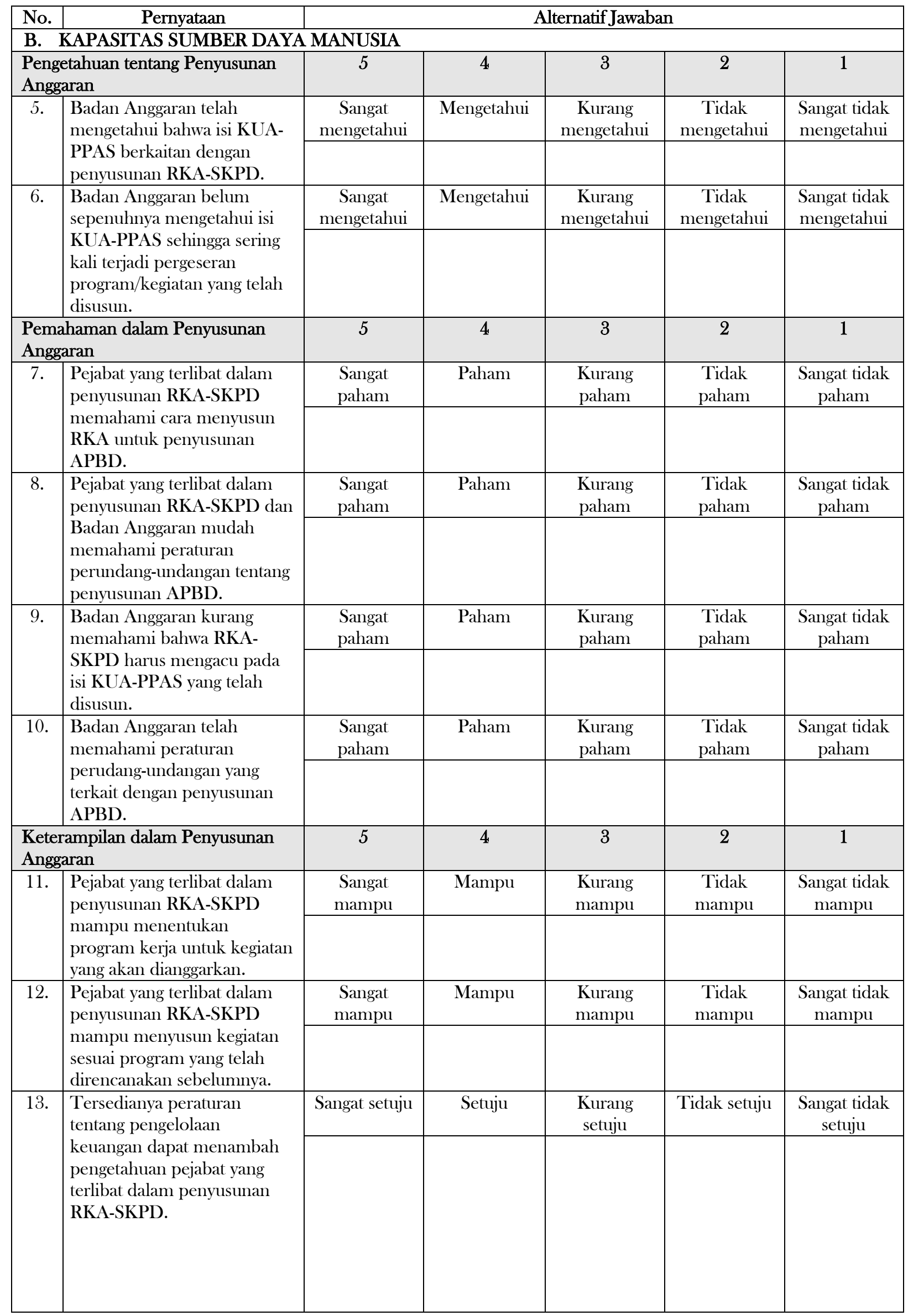




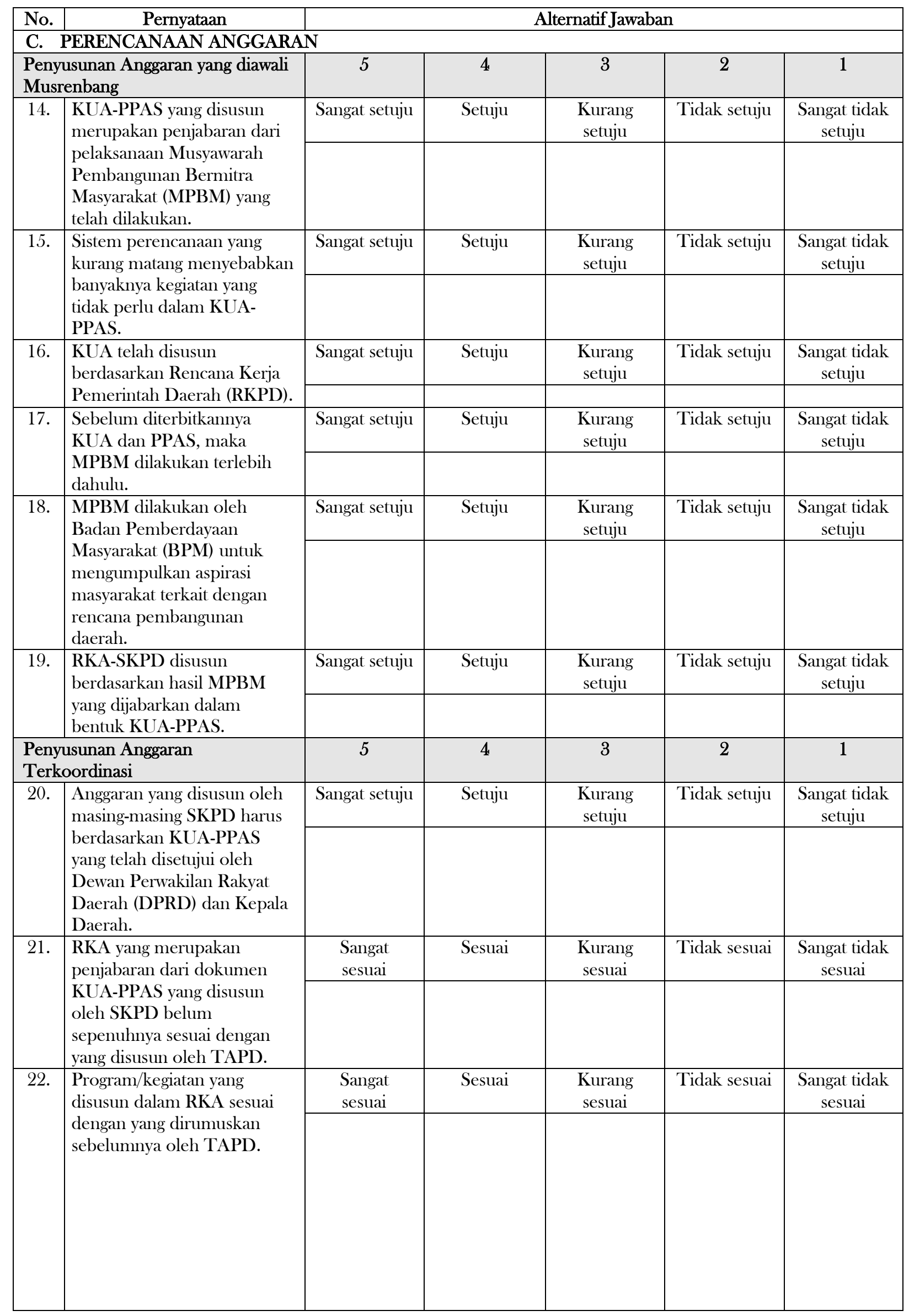




\begin{tabular}{|c|c|c|c|c|c|c|}
\hline \multirow{3}{*}{\multicolumn{2}{|c|}{\begin{tabular}{l|c} 
No. & Pernyataan \\
D. & POLITIK PENGANGGARAN \\
Unsur Kepentingan dalam
\end{tabular}}} & \\
\hline & & \multicolumn{5}{|c|}{$\begin{array}{c}\text { Alternatif Jawaban } \\
\end{array}$} \\
\hline & & 5 & 4 & 3 & 2 & 1 \\
\hline \multirow[t]{2}{*}{23.} & \multirow{2}{*}{\begin{tabular}{|l} 
Unsur kepentingan \\
berpengaruh pada \\
penambahan plafon dalam \\
penyusunan anggaran \\
sehingga menyebabkan \\
terjadinya perbedaan antara \\
dokumen KUA-PPAS \\
dengan dokumen APBD.
\end{tabular}} & Sangat setuju & Setuju & $\begin{array}{c}\begin{array}{c}\text { Kurang } \\
\text { setuju }\end{array} \\
\end{array}$ & Tidak setuju & $\begin{array}{c}\text { Sangat tidak } \\
\text { setuju }\end{array}$ \\
\hline & & & & & & \\
\hline \multirow[t]{2}{*}{24.} & \multirow{2}{*}{$\begin{array}{l}\text { Perubahan plafon atas } \\
\text { kegiatan-kegiatan yang } \\
\text { sebelumnya belum ada di } \\
\text { KUA dan PPAS dilakukan } \\
\text { bersama Badan Anggaran } \\
\text { dan TAPD. }\end{array}$} & Sangat setuju & Setuju & $\begin{array}{c}\text { Kurang } \\
\text { setuju }\end{array}$ & Tidak setuju & $\begin{array}{c}\text { Sangat tidak } \\
\text { setuju }\end{array}$ \\
\hline & & & & & & \\
\hline \multirow[t]{2}{*}{25.} & \multirow{2}{*}{$\begin{array}{l}\text { Perbedaan antara dokumen } \\
\text { KUA-PPAS dengan } \\
\text { dokumen APBD belum } \\
\text { sepenuhnya terlepas dari } \\
\text { unsur kepentingan sehingga } \\
\text { berpengaruh pada } \\
\text { perubahan plafon anggaran. }\end{array}$} & Sangat setuju & Setuju & $\begin{array}{c}\text { Kurang } \\
\text { setuju }\end{array}$ & Tidak setuju & $\begin{array}{c}\text { Sangat tidak } \\
\text { setuju }\end{array}$ \\
\hline & & & & & & \\
\hline \multirow[t]{2}{*}{26.} & \multirow{2}{*}{$\begin{array}{l}\text { Perubahan plafon } \\
\text { program/kegiatan oleh } \\
\text { Badan Anggaran yang } \\
\text { sebelumnya tidak tercantum } \\
\text { di KUA-PPAS dilakukan } \\
\text { atas dasar pertimbangan } \\
\text { tingkat kewajaran Anggaran. }\end{array}$} & Sangat setuju & Setuju & $\begin{array}{c}\text { Kurang } \\
\text { setuju }\end{array}$ & Tidak setuju & $\begin{array}{c}\text { Sangat tidak } \\
\text { setuju }\end{array}$ \\
\hline & & & & & & \\
\hline \multirow[t]{2}{*}{27.} & \multirow{2}{*}{$\begin{array}{l}\text { Badan Anggaran mempunyai } \\
\text { hak dalam melakukan } \\
\text { perubahan program dan } \\
\text { kegiatan jika program dan } \\
\text { kegiatan tersebut dianggap } \\
\text { tidak layak untuk } \\
\text { dilaksanakan. }\end{array}$} & Sangat setuju & Setuju & $\begin{array}{c}\text { Kurang } \\
\text { setuju }\end{array}$ & Tidak setuju & $\begin{array}{c}\text { Sangat tidak } \\
\text { setuju }\end{array}$ \\
\hline & & & & & & \\
\hline \multirow[t]{2}{*}{28.} & \multirow{2}{*}{$\begin{array}{l}\text { Kemampuan Badan } \\
\text { Anggaran dalam } \\
\text { memutuskan } \\
\text { program/kegiatan mana yang } \\
\text { tidak prioritas masih kurang } \\
\text { sehingga menyebabkan salah } \\
\text { dalam menentukan } \\
\text { perubahan program dan } \\
\text { kegiatan. } \\
\end{array}$} & $\begin{array}{c}\text { Sangat } \\
\text { mampu }\end{array}$ & Mampu & $\begin{array}{l}\text { Kurang } \\
\text { mampu }\end{array}$ & $\begin{array}{c}\text { Tidak } \\
\text { mampu }\end{array}$ & $\begin{array}{c}\text { Sangat tidak } \\
\text { mampu }\end{array}$ \\
\hline & & & & & & \\
\hline \multirow[t]{3}{*}{29.} & \multirow{3}{*}{$\begin{array}{l}\text { Politik penganggaran } \\
\text { berdampak baik dalam } \\
\text { penyusunan APBD karena } \\
\text { dapat mengakomodir } \\
\text { program/kegiatan yang } \\
\text { belum terakomodir di KUA- } \\
\text { PPAS. }\end{array}$} & Sangat baik & Baik & Kurang baik & Tidak baik & $\begin{array}{c}\text { Sangat tidak } \\
\text { baik }\end{array}$ \\
\hline & & & & & & \\
\hline & & & & & & \\
\hline
\end{tabular}




\begin{tabular}{|c|c|c|c|c|c|c|}
\hline No. & Pernyataan & \multicolumn{5}{|c|}{ Alternatif Jawaban } \\
\hline \multicolumn{2}{|c|}{$\begin{array}{l}\text { Bargaining Antara Eksekutif dan } \\
\text { Legislatif }\end{array}$} & 5 & 4 & 3 & 2 & 1 \\
\hline \multirow[t]{2}{*}{30.} & \multirow{2}{*}{$\begin{array}{l}\text { Perubahan plafon } \\
\text { program/kegiatan yang } \\
\text { diusulkan oleh Badan } \\
\text { Angggaran menyebabkan } \\
\text { perbedaan dokumen KUA- } \\
\text { PPAS dengan dokumen } \\
\text { APBD. }\end{array}$} & Sangat setuju & Setuju & $\begin{array}{c}\text { Kurang } \\
\text { setuju }\end{array}$ & Tidak setuju & $\begin{array}{l}\text { Sangat tidak } \\
\text { setuju }\end{array}$ \\
\hline & & & & & & \\
\hline \multirow[t]{2}{*}{31.} & \multirow{2}{*}{$\begin{array}{l}\text { Perubahan plafon } \\
\text { program/kegiatan yang } \\
\text { diusulkan oleh Badan } \\
\text { Anggaran disetujui oleh } \\
\text { TAPD. }\end{array}$} & Sangat setuju & Setuju & $\begin{array}{c}\text { Kurang } \\
\text { setuju }\end{array}$ & Tidak setuju & $\begin{array}{c}\text { Sangat tidak } \\
\text { setuju }\end{array}$ \\
\hline & & & & & & \\
\hline \multirow[t]{2}{*}{32.} & \multirow{2}{*}{$\begin{array}{l}\text { TAPD menyetujui } \\
\text { perubahan plafon } \\
\text { program/kegiatan setelah } \\
\text { melalui berbagai } \\
\text { pertimbangan Badan } \\
\text { Anggaran. }\end{array}$} & Sangat setuju & Setuju & $\begin{array}{c}\text { Kurang } \\
\text { setuju }\end{array}$ & Tidak setuju & $\begin{array}{l}\text { Sangat tidak } \\
\text { setuju }\end{array}$ \\
\hline & & & & & & \\
\hline \multirow[t]{2}{*}{33.} & \multirow{2}{*}{$\begin{array}{l}\text { TAPD berusaha } \\
\text { mempertahankan program } \\
\text { dan kegiatan yang telah } \\
\text { disusun dengan memberikan } \\
\text { penjelasan dan pertimbangan } \\
\text { mengenai pelaksanaan } \\
\text { program dan kegiatan } \\
\text { tersebut. }\end{array}$} & Sangat setuju & Setuju & $\begin{array}{c}\text { Kurang } \\
\text { setuju }\end{array}$ & Tidak setuju & $\begin{array}{l}\text { Sangat tidak } \\
\text { setuju }\end{array}$ \\
\hline & & & & & & \\
\hline \multirow[t]{2}{*}{34.} & \multirow{2}{*}{$\begin{array}{l}\text { Perubahan program/kegiatan } \\
\text { oleh Badan Anggaran } \\
\text { dikarenakan SKPD tidak } \\
\text { dapat mempertahankan dan } \\
\text { memberikan alasan mengapa } \\
\text { anggaran program/kegiatan } \\
\text { tersebut dianggarkan. }\end{array}$} & Sangat setuju & Setuju & $\begin{array}{c}\text { Kurang } \\
\text { setuju }\end{array}$ & Tidak setuju & $\begin{array}{l}\text { Sangat tidak } \\
\text { setuju }\end{array}$ \\
\hline & & & & & & \\
\hline \multicolumn{7}{|c|}{ E. KEBIJAKAN PUBLIK } \\
\hline \multicolumn{2}{|c|}{ Sasaran Kebijakan } & 5 & 4 & 3 & 2 & 1 \\
\hline \multirow[t]{2}{*}{35.} & \multirow{2}{*}{$\begin{array}{l}\text { Program dan kegiatan di } \\
\text { dalam dokumen KUA-PPAS } \\
\text { telah berdasarkan hasil } \\
\text { MPBM yang menyasar } \\
\text { kepada kepentingan } \\
\text { masyarakat. }\end{array}$} & Sangat setuju & Setuju & $\begin{array}{c}\text { Kurang } \\
\text { setuju }\end{array}$ & Tidak setuju & $\begin{array}{l}\text { Sangat tidak } \\
\text { setuju }\end{array}$ \\
\hline & & & & & & \\
\hline \multirow[t]{2}{*}{36.} & \multirow{2}{*}{$\begin{array}{l}\text { Program dan kegiatan di } \\
\text { dalam Dokumen KUA- } \\
\text { PPAS hasil MPBM } \\
\text { bertujuan menciptakan } \\
\text { kesejahteraan masyarakat. }\end{array}$} & Sangat setuju & Setuju & $\begin{array}{c}\text { Kurang } \\
\text { setuju }\end{array}$ & Tidak setuju & $\begin{array}{l}\text { Sangat tidak } \\
\text { setuju }\end{array}$ \\
\hline & & & & & & \\
\hline \multicolumn{2}{|c|}{ Rencana Kebijakan } & 5 & 4 & 3 & 2 & 1 \\
\hline \multirow[t]{2}{*}{37.} & \multirow{2}{*}{$\begin{array}{l}\text { Rencana program dan } \\
\text { kegiatan dalam dokumen } \\
\text { KUA-PPAS telah } \\
\text { didiskusikan dan dibuat } \\
\text { sesuai dengan tujuan dan } \\
\text { sasarannya. }\end{array}$} & Sangat setuju & Setuju & $\begin{array}{c}\text { Kurang } \\
\text { setuju }\end{array}$ & Tidak setuju & $\begin{array}{c}\text { Sangat tidak } \\
\text { setuju }\end{array}$ \\
\hline & & & & & & \\
\hline
\end{tabular}




\begin{tabular}{|c|c|c|c|c|c|c|}
\hline \multirow{2}{*}{\multicolumn{2}{|c|}{\begin{tabular}{l|r} 
No. & Pernyataan \\
Program dan Turunannya
\end{tabular}}} & \multicolumn{5}{|c|}{ Alternatif Jawaban } \\
\hline & & 5 & 4 & 3 & 2 & 1 \\
\hline \multirow[t]{2}{*}{38.} & \multirow{2}{*}{$\begin{array}{l}\text { Program dan kegiatan dalam } \\
\text { dokumen KUA-PPAS dapat } \\
\text { menjadi alat formal untuk } \\
\text { mencapai tujuan yaitu untuk } \\
\text { kepentingan publik. }\end{array}$} & Sangat setuju & Setuju & $\begin{array}{l}\text { Kurang } \\
\text { setuju }\end{array}$ & Tidak setuju & $\begin{array}{l}\text { Sangat tidak } \\
\text { setuju }\end{array}$ \\
\hline & & & & & & \\
\hline \multicolumn{2}{|c|}{$\begin{array}{l}\text { Keputusan sebagai Tindakan untuk } \\
\text { Mencapai Tujuan }\end{array}$} & 5 & 4 & 3 & 2 & 1 \\
\hline \multirow[t]{2}{*}{39.} & \multirow{2}{*}{$\begin{array}{l}\text { KUA-PPAS yang merupakan } \\
\text { hasil keputusan bersama } \\
\text { telah melalui siklus utuh yang } \\
\text { meliputi kegiatan } \\
\text { perencanaan hingga evaluasi. }\end{array}$} & Sangat setuju & Setuju & $\begin{array}{c}\text { Kurang } \\
\text { setuju }\end{array}$ & Tidak setuju & $\begin{array}{l}\text { Sangat tidak } \\
\text { setuju }\end{array}$ \\
\hline & & & & & & \\
\hline \multicolumn{2}{|c|}{ Dampak Pelaksanaan Program } & 5 & 4 & 3 & 2 & 1 \\
\hline \multirow[t]{2}{*}{40.} & \multirow{2}{*}{$\begin{array}{l}\text { Seluruh program dan } \\
\text { kegiatan yang disusun dalam } \\
\text { dokumen KUA-PPAS telah } \\
\text { memperhitungkan dampak } \\
\text { dari pelaksanaannya. } \\
\end{array}$} & Sangat setuju & Setuju & $\begin{array}{c}\text { Kurang } \\
\text { setuju }\end{array}$ & Tidak setuju & $\begin{array}{c}\text { Sangat tidak } \\
\text { setuju }\end{array}$ \\
\hline & & & & & & \\
\hline \multicolumn{7}{|c|}{ F. TRANSPARANSI PUBLIK } \\
\hline \multicolumn{2}{|c|}{$\begin{array}{l}\text { Ketersediaan dan Kemudahan } \\
\text { Akses Dokumen Anggaran }\end{array}$} & 5 & 4 & 3 & 2 & 1 \\
\hline \multirow[t]{2}{*}{41.} & \multirow{2}{*}{$\begin{array}{l}\text { Dokumen APBD dan KUA- } \\
\text { PPAS yang dipublikasikan } \\
\text { dapat meningkatkan } \\
\text { transparansi anggaran } \\
\text { terhadap masyarakat. }\end{array}$} & $\begin{array}{l}\text { Sangat } \\
\text { mampu }\end{array}$ & Mampu & $\begin{array}{l}\text { Kurang } \\
\text { mampu }\end{array}$ & $\begin{array}{c}\text { Tidak } \\
\text { mampu }\end{array}$ & $\begin{array}{c}\text { Sangat tidak } \\
\text { mampu }\end{array}$ \\
\hline & & & & & & \\
\hline \multicolumn{2}{|c|}{ Pengumuman Kebijakan Anggaran } & 5 & 4 & 3 & 2 & 1 \\
\hline \multirow[t]{2}{*}{42.} & \multirow{2}{*}{$\begin{array}{l}\text { Dokumen APBD dan KUA- } \\
\text { PPAS dapat diakses oleh } \\
\text { masyarakat. }\end{array}$} & $\begin{array}{l}\text { Sangat } \\
\text { mampu }\end{array}$ & Mampu & $\begin{array}{l}\text { Kurang } \\
\text { mampu }\end{array}$ & $\begin{array}{c}\text { Tidak } \\
\text { mampu }\end{array}$ & $\begin{array}{c}\text { Sangat tidak } \\
\text { mampu }\end{array}$ \\
\hline & & & & & & \\
\hline \multicolumn{2}{|c|}{$\begin{array}{l}\text { Dokumen Anggaran yang Tepat } \\
\text { Waktu }\end{array}$} & 5 & 4 & 3 & 2 & 1 \\
\hline 43. & $\begin{array}{l}\text { Penyampaian dokumen } \\
\text { APBD dan KUA-PPAS }\end{array}$ & $\begin{array}{c}\text { Sangat tepat } \\
\text { waktu }\end{array}$ & Tepat waktu & $\begin{array}{l}\text { Kurang tepat } \\
\text { waktu }\end{array}$ & $\begin{array}{l}\text { Tidak tepat } \\
\text { waktu }\end{array}$ & $\begin{array}{l}\text { Sangat tidak } \\
\text { tepat waktu }\end{array}$ \\
\hline & disampaikan tepat waktu. & & & & & \\
\hline \multicolumn{2}{|c|}{$\begin{array}{l}\text { Akomodasi terhadap Aspirasi } \\
\text { Masyarakat }\end{array}$} & 5 & 4 & 3 & 2 & 1 \\
\hline \multirow[t]{2}{*}{44.} & \multirow{2}{*}{$\begin{array}{l}\text { Transparansi publik dapat } \\
\text { mengakomodasi dan } \\
\text { meningkatkan partisipasi } \\
\text { masyarakat terhadap } \\
\text { anggaran. }\end{array}$} & $\begin{array}{l}\text { Sangat } \\
\text { mampu }\end{array}$ & Mampu & $\begin{array}{l}\text { Kurang } \\
\text { mampu }\end{array}$ & $\begin{array}{c}\text { Tidak } \\
\text { mampu }\end{array}$ & $\begin{array}{c}\text { Sangat tidak } \\
\text { mampu }\end{array}$ \\
\hline & & & & & & \\
\hline \multicolumn{2}{|c|}{$\begin{array}{l}\text { Terdapat Sistem Pemberian } \\
\text { Informasi }\end{array}$} & 5 & 4 & 3 & 2 & 1 \\
\hline \multirow[t]{2}{*}{45.} & \multirow{2}{*}{$\begin{array}{l}\text { Informasi tentang dokumen } \\
\text { APBD dan KUA PPAS } \\
\text { mudah diperoleh setiap } \\
\text { waktu. }\end{array}$} & $\begin{array}{l}\text { Sangat } \\
\text { mudah }\end{array}$ & Mudah & $\begin{array}{l}\text { Kurang } \\
\text { mudah }\end{array}$ & $\begin{array}{l}\text { Tidak } \\
\text { mudah }\end{array}$ & $\begin{array}{l}\text { Sangat tidak } \\
\text { mudah }\end{array}$ \\
\hline & & & & & & \\
\hline
\end{tabular}

